\title{
Boundary layer concentrations and landscape scale emissions of volatile organic compounds in early spring
}

\author{
S. Haapanala ${ }^{1}$, J. Rinne ${ }^{1}$, H. Hakola ${ }^{2}$, H. Hellén ${ }^{2}$, L. Laakso ${ }^{1}$, H. Lihavainen ${ }^{3}$, R. Janson ${ }^{4}$, C. O'Dowd ${ }^{5}$, and \\ M. Kulmala ${ }^{1}$ \\ ${ }^{1}$ University of Helsinki, Department of Physical Sciences, Helsinki, Finland \\ ${ }^{2}$ Finnish Meteorological Institute, Air Chemistry Laboratory, Helsinki, Finland \\ ${ }^{3}$ Finnish Meteorological Institute, Climate and Global Change Research, Helsinki, Finland \\ ${ }^{4}$ Stockholm University, Department of Applied Environmental Science, Stockholm, Sweden \\ ${ }^{5}$ National University of Ireland, Department of Physics, Galway, Ireland
}

Received: 4 October 2006 - Published in Atmos. Chem. Phys. Discuss.: 18 October 2006

Revised: 20 February 2007 - Accepted: 3 April 2007 - Published: 16 April 2007

\begin{abstract}
Boundary layer concentrations of several volatile organic compounds (VOC) were measured during two campaigns in springs of 2003 and 2006. The measurements were conducted over boreal landscapes near SMEAR II measurement station in Hyytiälä, Southern Finland. In 2003 the measuremens were performed using a light aircraft and in 2006 using a hot air balloon. Isoprene concentrations were low, usually below detection limit. This can be explained by low biogenic production due to cold weather, phenological stage of the isoprene emitting plants, and snow cover. Monoterpenes were observed frequently. The average total monoterpene concentration in the boundary layer was $33 \mathrm{ppt}_{v}$. Many anthropogenic compounds such as benzene, xylene and toluene, were observed in high amounts. Ecosystem scale surface emissions were estimated using a simple mixed box budget methodology. Total monoterpene emissions varied up to $80 \mu \mathrm{g} \mathrm{m}^{-2} \mathrm{~h}^{-1}, \alpha$-pinene contributing typically more than two thirds of that. These emissions were somewhat higher that those calculated using emission algorithm. The highest emissions of anthropogenic compounds were those of $\mathrm{p} / \mathrm{m}$ xylene.
\end{abstract}

\section{Introduction}

Atmospheric aerosol particles are important for the global radiation budget (Seinfeld and Pandis, 1998; Twomey, 1991; Ramanathan et al., 2001; Cess et al., 1995; Kurten et al., 2003; Kulmala et al., 2004a). In addition to anthropogenic sources, biogenic activities increase significantly the aerosol load (e.g. Tunved et al., 2006). Substantial production of new aerosol particles has been observed in forested boreal re-

Correspondence to: S. Haapanala

(sami.haapanala@helsinki.fi) gion (Mäkelä et al., 1997; Kulmala et al., 2004b). The maximum of new aerosol particle formation in these areas occurs in the spring (Dal Maso et al., 2005). Aerosol formation and especially growth in rural areas are expected to be caused mainly by terpenoid compounds and their oxidation products (O’Dowd et al., 2002; Tunved et al., 2006). To understand the details of these formation and growth processes, it is important to know the concentrations and sources of condensable vapors in the atmosphere. Atmospheric concentration of any trace gas depends on transport, sources, sinks and chemistry of the compound in question. Surface- and boundary layer concentrations of volatile organic compounds (VOC) in European boreal region have been measured by various investigators (e.g. Janson et al., 1992; Hakola et al., 2000, 2003, 2006a; Spirig et at., 2004; Rinne et al., 2005).

Classical nucleation theories suggest that high saturation ratio of condensable vapors leads to nucleation. High saturation ratio can be obtained by lowering the temperature, or by increasing the concentration. The highest concentrations of condensable compounds occurs usually just above the canopy while lowest temperatures are observed at the top of the boundary layer. In addition to saturation ratio, several other factors have effects on nucleation. These include relative humidity, pre-existing particle surface and turbulent mixing. These partly contradicting requirements make it almost impossible to predict where in the boundary layer the formation of new particles actually takes place, and which are the most important factors affecting it.

VOC emissions can be estimated on different scales by different techniques. Branch scale VOC emissions of typical tree species in the boreal areas have been measured using chambers by e.g. Janson (1993), Hakola et al. (1998, 2006b) and Tarvainen et al. (2005). On the ecosystem scale VOC emissions from boreal forests have been measured

Published by Copernicus GmbH on behalf of the European Geosciences Union. 
Table 1. A summary of flights including start and end time of the measurement period, duration of that period, average canopy level air temperature, and above canopy photosynthetic photon flux density (PPFD) during the measurements.

\begin{tabular}{llllll}
\hline Date & Start time & End time & Duration & Temperature & PPFD \\
\hline [dd/mm/yy $]$ & {$[\mathrm{hh}: \mathrm{mm}]$} & {$[\mathrm{hh}: \mathrm{mm}]$} & {$[\mathrm{min}]$} & {$\left[{ }^{\circ} \mathrm{C}\right]$} & {$\left[\mu \mathrm{mol} \mathrm{m}^{-2} \mathrm{~s}^{-1}\right]$} \\
\hline QUEST II 2003, light aircraft & & & & \\
21 March 2003 & $13: 07$ & $13: 32$ & 25 & -3 & 900 \\
25 March 03 & $12: 10$ & $14: 00$ & 110 & 4 & 950 \\
26 March 03 & $11: 32$ & $12: 41$ & 69 & 6 & 930 \\
27 March 03 & $09: 47$ & $10: 17$ & 30 & 3 & 700 \\
28 March 03 & $08: 55$ & $10: 17$ & 82 & 2 & 750 \\
28 March 03 & $10: 46$ & $11: 59$ & 73 & 4 & 980 \\
28 March 03 & $14: 41$ & $16: 10$ & 89 & 5 & 800 \\
2 April 2003 & $11: 50$ & $12: 50$ & 60 & -3 & 550 \\
LABACET 2006, hot air balloon & & & \\
10 March 2006 & $13: 35$ & $14: 14$ & 39 & -9 & 550 \\
12 March 2006 & $14: 56$ & $15: 17$ & 21 & -4 & 550 \\
13 March 2006 & $13: 58$ & $14: 28$ & 30 & 1 & 630 \\
14 March 2006 & $11: 43$ & $12: 08$ & 25 & -2 & 810 \\
17 March 2006 & $14: 17$ & $14: 53$ & 36 & 5 & 500 \\
\hline
\end{tabular}

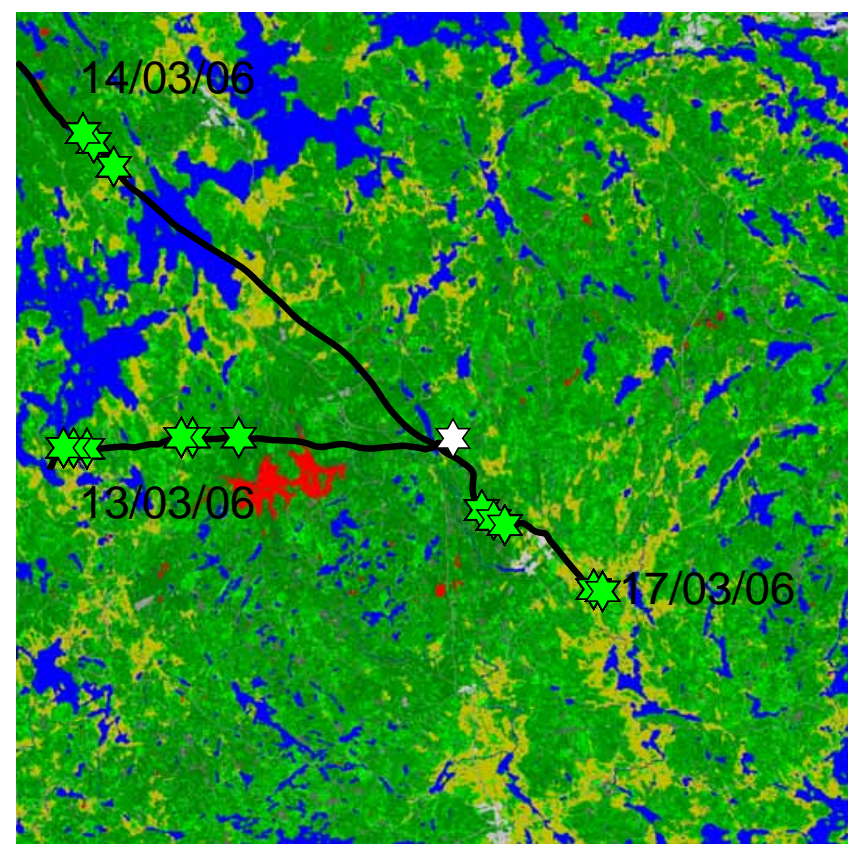

Fig. 1. A map of the land use around SMEAR II station. The location of the station is indicated with a white star in the middle of the picture. The area shown is $40 \times 40 \mathrm{~km}^{2}$. Shades of green are forests, yellow are agricultural lands, red are wetlands and blue are water bodies. Black lines show the routes of three balloon flights. Green stars indicate balloon locations when VOC sampling was conducted. Map material: Copyright National Land Survey of Finland 2002.
Table 2. The proportions of different land use categories in the area of $1600 \mathrm{~km}^{2}$ around SMEAR II station.

\begin{tabular}{ll}
\hline Land use type & Proportion [\%] \\
\hline built areas & 0.3 \\
wetlands & 0.7 \\
clear cut & 1.7 \\
deciduous forest & 2.0 \\
open land & 2.9 \\
agriculture & 10.2 \\
water bodies & 13.0 \\
mixed forest & 20.9 \\
pine dominated forest & 22.7 \\
spruce dominated forest & 25.5 \\
\hline
\end{tabular}

by e.g. Rinne et al. $(1999,2000 a, 2000 b)$ and Spanke et al. (2001). These studies proved boreal vegetation to be strong monoterpene emitters, with some sesquiterpene and isoprene emissions as well.

Surface emissions on the landscape scale can be estimated using boundary layer concentrations. Davis et al. (1994) performed first measurements of landscape scale hydrocarbon emissions using a mixed-layer gradient technique. They measured isoprene and monoterpene concentrations in the lower part of the boundary layer above tropical rainforest in Amazonas, Brazil and mixed pine-oak forest in Alabama, USA. In the boreal region Spirig et al. (2004) have measured boundary layer concentrations of isoprene and monoterpenes using tethered balloon in the Southern Finland in summer- 
time. They used both mixed-layer gradient and mixed box budget methods and estimated the surface fluxes of monoterpenes to be between 180 and $300 \mu \mathrm{g} \mathrm{m}^{-2} \mathrm{~h}^{-1}$ in August 2001. However, no previous measurements in these regions in early spring, which is the maximum particle formation season, have been reported. In addition, there is not much information on the boundary layer concentrations of the anthropogenic compounds in the rural areas of northern Europe.

In the present study, we measured concentrations of several non-methane hydrocarbons throughout the boundary layer. In addition, we calculated estimates for the landscape scale surface emissions of these compounds. Our measurements were conducted in early spring when events of new aerosol particle formation are often observed in boreal areas. An extensive set of aerosol measurements were performed simultaneously.

\section{Materials and methods}

The measurements were performed during QUEST II (Quantification of Aerosol Nucleation in the European Boundary Layer) measurement campaign in 2003 (hereafter referred to "QUEST II 2003") and LABACET (LAgrangian Balloonborne Aerosol Characterization ExperimenT) experiment in 2006 (hereafter referred to "LABACET 2006"). In QUEST II 2003 the measurements were carried out between 21 March 2003 and 2 April 2003 using a light aircraft. In LABACET 2006 the measurements were conducted between 10 March 2006 and 17 March 2006 using a hot air balloon as a measurement platform. Table 1 summarizes the flights and some of the basic atmospheric properties during them. Despite of some longer flights, only samples taken within $45 \mathrm{~min}$ were accepted to represent one profile. Figure 1 shows three examples of hot air balloon routes and the location when VOC sampling was conducted. In Fig. 2 altitude curves of the same flights with VOC sampling points are shown. Due to problems with GPS data, routes of all flights are not available.

The measurements took place near SMEAR II measurement station, located in Southern Finland $\left(61^{\circ} 51^{\prime} \mathrm{N}\right.$, $24^{\circ} 17^{\prime} \mathrm{E}, 180 \mathrm{~m}$ a.s.l.). The area belongs to the southern boreal zone. Vegetation consists mainly of coniferous trees, dominated by Scots pine (Pinus sylvestris) and Norway spruce (Picea abies). Figure 1 shows the different land use categories around SMEAR II station. In Table 2 the proportional abundances of different categories are given. The land use data is derived from satellite photographs and forest inventories by National Land Survey of Finland and has a resolution of $25 \times 25 \mathrm{~m}$.

The annual mean temperature in the area is $3^{\circ} \mathrm{C}$. The warmest month is July with mean temperature of $16^{\circ} \mathrm{C}$ and the coldest is February with mean temperature of $-8^{\circ} \mathrm{C}$. The annual mean precipitation is $700 \mathrm{~mm}$. These climatological
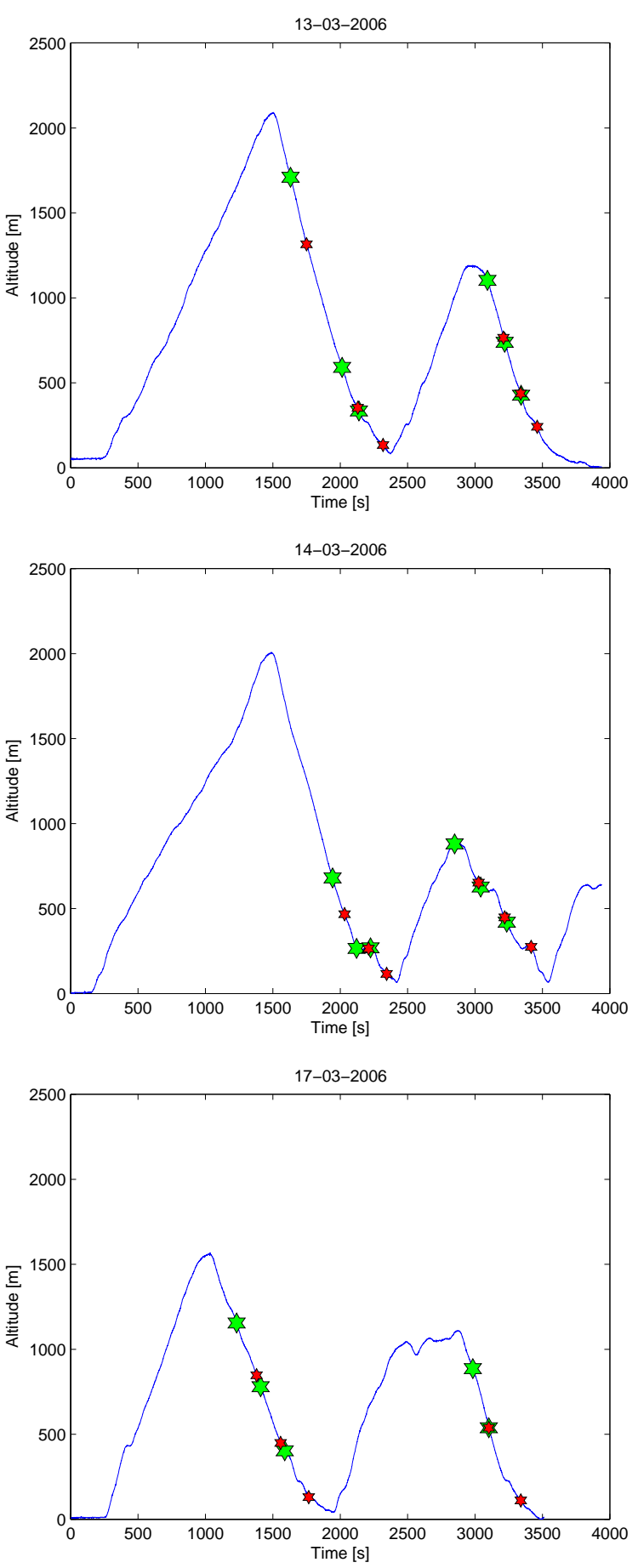

Fig. 2. Cruise altitude during the balloon flights shown in Fig. 1. Green stars indicate balloon locations when VOC sampling was started and red stars locations where sampling was stopped.

statistics are from Juupajoki-Hyytiälä meteorological station, located about $500 \mathrm{~m}$ east from the SMEAR II measurement station and the data represents period 1971-2000 (Drebs et 

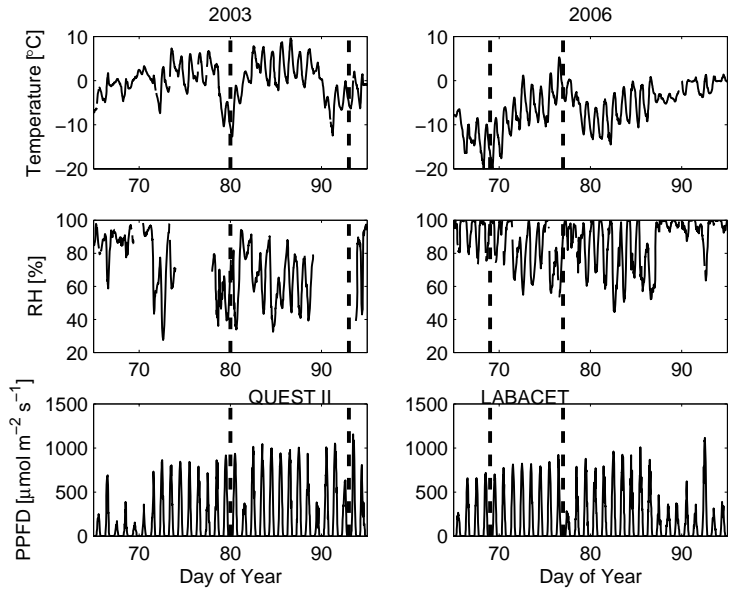

Fig. 3. Air temperature and relative humidity at $8 \mathrm{~m}$ height and photosynthetic photon flux density (PPFD) above forest canopy during springs 2003 and 2006. Time periods of the measurement campaigns are marked in the figures.
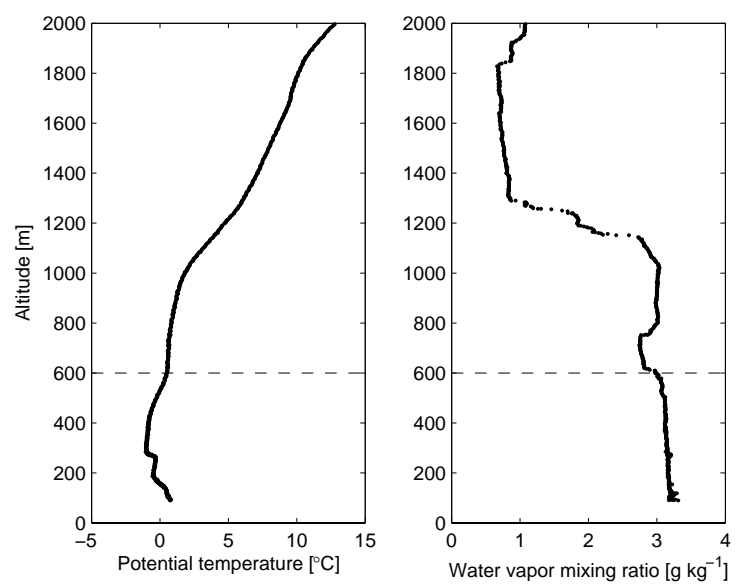

Fig. 4. Vertical profiles of potential temperature (left panel) and water vapor mixing ratio (right panel) on 13 March 2006. The black line shows subjectively approximated height of the boundary layer top.

\section{al., 2002).}

At the SMEAR II measurement station many environmental parameters are measured routinely (Hari and Kulmala, 2005). These include various aerosol measurements, concentrations and surface fluxes of $\mathrm{H}_{2} \mathrm{O}, \mathrm{CO}_{2}$ and $\mathrm{O}_{3}$ as well as ordinary meteorological parameters. In Fig. 3 air temperature and relative humidity measured at $8 \mathrm{~m}$ height and photosynthetic photon flux density measured above forest during springs 2003 and 2006 are shown. Spring 2003, with mean temperature around zero, was clearly warmer than spring 2006.

Both aircraft and hot air balloon were equipped with tem- perature and humidity sensors. These were used to determine the top of the boundary layer. This was done subjectively from the potential temperature and water vapour mixing ratio data. The top of the boundary layer was assumed to be at the height where water vapour mixing ratio has a strong change or potential temperature gradient changes to positive. In Fig. 4, one typical case (13 March 2006) is shown.

The measurement platform during QUEST II 2003 flights was a DHC-6/300 Twin Otter STOL fixed-wing, twin engine aircraft $\mathrm{OH}-\mathrm{KOG}$. The airflow for VOC samples was taken in through a pitot tube located at the roof of the aircraft, in front of the engines. Dynamic pressure of the pitot tube generated a flow through $3 \mathrm{~m}$ of Teflon tubing which had an outlet below the aircraft. The total airflow at the sample inlet was much higher than required for VOC sampling devices. Sampler devices were connected to this line. For more details of the sampling system, see O'Dowd et al. (2007). The measurement platform during LABACET 2006 flights was an Ultramagic S-130 hot air balloon OH-SOL with an Ultramagic C-6 gondola and a MK-21 burner. To avoid the contaminants produced by the burner, the measurements were performed only during descend of the balloon, when there is strong flow of unaffected air from below the gondola and when the usage of burner is minimal. In addition, the samples were collected about two meters below the gondola base. From the data of aerosol particle number concentration, temperature and humidity, it was confirmed that these procedures were adequate to guarantee contamination free measurements.

Light $\mathrm{C}_{2}-\mathrm{C}_{6}$ hydrocarbons were sampled into 0.851 electro polished stainless steel canisters. The canisters were evacuated beforehand and pressurized during sampling using Teflon coated pump. The duration of one canister filling was $60-180 \mathrm{~s}$. Chemical analysis of these samples was performed using a gas chromatograph (HP-6890) with a flame ionization detector (FID).

Heavier $\mathrm{C}_{5}-\mathrm{C}_{10}$ hydrocarbons were trapped into cartridges filled with Tenax-TA and Carbopack-B adsorbents. The samples were taken using 10-min sampling time and constant flow of about 0.261 per minute in the QUEST II campaign. During the LABACET experiment only 1- to 4-min sampling times were possible. Therefore we had to use a sampling flow of about 0.451 per minute. At this high flow rate a breakthrough can be a significant problem and hence we used two cartridges installed in series. The concentrations analysed from these two cartridges were summed to yield the total concentration. On average $90 \%$ of the measured total monoterpene concentration was trapped in the first cartridge. The adsorbent samples were analyzed using automatic thermodesorption device (Perkin-Elmer ATD-400) connected to a gas chromatograph (HP-5890) and a mass-selective detector (HP-5972). For more details on the analysis systems used for airborne samples, see Hakola et al. (2000).

During the QUEST II 2003 campaign, additional surface layer concentration measurements of monoterpenes were conducted at the top of the SMEAR II tower, above the 
Table 3. A summary of sampling methods during the projects.

\begin{tabular}{|c|c|c|c|c|c|c|}
\hline Measurement & $\begin{array}{l}\text { Sampling } \\
\text { method }\end{array}$ & & $\begin{array}{l}\text { Sampling flow } \\
\text { rate }[\mathrm{ml} \mathrm{min}-1]\end{array}$ & $\begin{array}{l}\text { Sampling time } \\
\text { [min] }\end{array}$ & $\begin{array}{l}\text { Analytical } \\
\text { method }\end{array}$ & Measured compounds \\
\hline \multicolumn{7}{|c|}{ QUEST II 2003} \\
\hline Ground & Tenax-TA & & 50 & 120 & $\begin{array}{l}\text { thermodesorption- } \\
\text { GC-MS }\end{array}$ & monoterpenes \\
\hline Aircraft & canister & & & 1 & GC-FID & benzene, isoprene \\
\hline Aircraft & $\begin{array}{l}\text { Tenax-TA } \\
\text { Carbopack-B }\end{array}$ & $\&$ & 260 & 10 & $\begin{array}{l}\text { thermodesorption- } \\
\text { GC-MS }\end{array}$ & $\begin{array}{l}\text { monoterpenes, aro- } \\
\text { matic hydrocarbons }\end{array}$ \\
\hline \multicolumn{7}{|c|}{ LABACET 2006} \\
\hline Balloon & canister & & & $1-3$ & GC-FID & benzene, isoprene \\
\hline Balloon & $\begin{array}{l}\text { Tenax-TA } \\
\text { Carbopack-B }\end{array}$ & $\&$ & 450 & $1-4$ & $\begin{array}{l}\text { thermodesorption- } \\
\text { GC-MS }\end{array}$ & $\begin{array}{l}\text { monoterpenes, aro- } \\
\text { matic hydrocarbons }\end{array}$ \\
\hline
\end{tabular}

forest canopy. These samples were collected on TenaxTA at $50 \mathrm{ml} \mathrm{min}^{-1}$ for $2 \mathrm{~h}$ per sample. A sampler system with timers and solenoid valves was used to enable sampling around the clock for the duration of the campaign. The samples were analysed in the laboratory by ATD-GC-MS. For more details on the sampling and analysis system of surface measurements, see Janson et al. (2001). Table 3 summarizes all sampling procedures during these projects.

In order to estimate the magnitude of the surface emission, we used a simple mixed box budget method (e.g. Guenther et al., 1996). In this method, the mixed boundary layer is treated as a closed and well mixed box where sources (surface emission) and sinks (chemical loss and entrainment) are in balance. Here we assume that these processes are constant in time and space, causing the mean concentrations of the compounds to be constant as well. The entrainment flux at the top of the boundary layer can be estimated using jump model where flux equals to product of concentration difference across the boundary layer top and the growth rate of the boundary layer. Guenther et al. (1996) and Spirig et al. (2004) showed that in their studies neglecting entrainment would lead to less than $20 \%$ underestimation in the surface flux. Due to lack of good estimates of boundary layer growth rate, the entrainment flux at the top of the boundary layer is neglected in this study. This leads, on average, to similar underestimation in the surface flux as in the studies cited above, as will be shown in Results and discussion. After these assumptions we can write

$F=z S$,

where $F$ is the surface flux, $z$ is the height of the boundary layer and $S$ is the chemical loss rate.

The chemical loss rates for different hydrocarbons were estimated from their reactions with ozone $\left(\mathrm{O}_{3}\right)$ and hydroxyl radical $(\mathrm{OH})$. Ozone concentration was measured at the top of the SMEAR II mast, $67 \mathrm{~m}$ above the ground level. Although measured in the lowest part of the boundary layer, this data was assumed to represent the whole mixed boundary layer with reasonable accuracy. This data was used directly to estimate the loss rate of hydrocarbons caused by ozone. The typical monthly mean daytime concentrations of $\mathrm{OH}$ were adopted directly from Hakola et al. (2003). They calculated daytime concentration of $\mathrm{OH}$ using a photochemical model. The model was initialized using data from year 2000, measured in the vicinity of SMEAR II station. The mean $\mathrm{OH}$ concentrations were $0.013 \mathrm{ppt}$ and $0.030 \mathrm{ppt}$ for March and April, respectively. Real instantaneous values may differ significantly from these typical values. From the differences between mean concentrations of successive months in the spring, it was estimated that the actual concentration may differ from mean values even with a factor of about 3 . This conclusion is supported by the model data presented by Boy et al. (2005). Reactions of hydrocarbons with nitrate radical $\left(\mathrm{NO}_{3}\right)$ were ignored because they are important only during night time. Loss rates were calculated from

$S=\mathrm{c}_{\mathrm{VOC}}\left(\mathrm{c}_{\mathrm{O}_{3}} \mathrm{k}_{\mathrm{O}_{3}}+\mathrm{c}_{\mathrm{OH}} \mathrm{k}_{\mathrm{OH}}\right)$,

where $c_{\text {VOC }}$ is the concentration of a particular VOC compound, $\mathrm{c}_{\mathrm{O} 3}$ and $\mathrm{c}_{\mathrm{OH}}$ are the concentrations of $\mathrm{O}_{3}$ and $\mathrm{OH}$, respectively, and $\mathrm{k}_{\mathrm{O} 3}$ and $\mathrm{k}_{\mathrm{OH}}$ are the corresponding second order rate coefficients. Average boundary layer concentrations were obtained by trapezoid integrals. Integration was conducted from the lowest measured point up to the top of the boundary layer. The uppermost concentration measurement was extrapolated to represent the concentration at the top of the boundary layer. The concentrations that were below the detection limit of the chemical analysis were converted to the value of detection limit divided by two. 

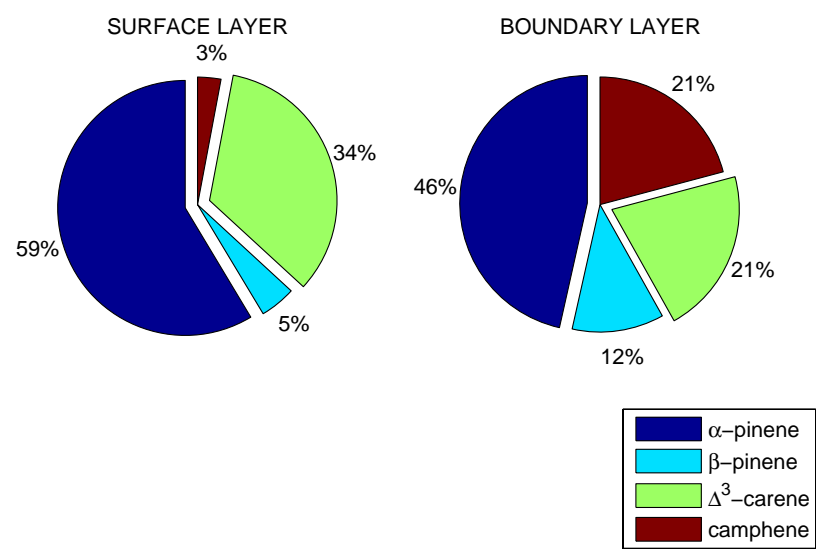

Fig. 5. Relative abundances of different monoterpenes during QUEST II 2003 in the surface layer (left panel) and upper in the boundary layer (right panel).

\section{Results and discussion}

3.1 Boundary layer concentrations of volatile organic compounds

Statistics of the VOC concentrations measured during the whole campaigns are presented in Table 4 . Isoprene concentration exceeded the detection limit $\left(\approx 10 \mathrm{ppt}_{v}\right)$ only in two samples. Isoprene is known to be emitted by many boreal plant species (e.g. Hakola et al., 1998; Hellén et al., 2006; Haapanala et al., 2006) directly from synthesis which is light and temperature dependent (Guenther et al., 1993). The absence of isoprene can be explained by three factors: early time of year, cold weather at the time of the measurements, and relatively low coverage of isoprene forming plants. Due to early time of year isoprene emitting deciduous trees did not have leaves yet and ground vegetation, such as sphagnum mosses in wetlands, was covered by snow. Cold weather alone could have explained low concentration of isoprene on most of the days.

Monoterpenes were observed frequently throughout the boundary layer. Figure 5 shows relative abundances of different monoterpenes in the surface layer and in the boundary layer. In this comparison only data from QUEST II 2003 was used. The most abundant monoterpene was $\alpha$-pinene with average daytime surface concentration of $37 \mathrm{ppt}_{v}$ and boundary layer concentration of $18 \mathrm{ppt}_{v}$. The second most abundant monoterpene was $\Delta^{3}$-carene. Contribution of camphene was strongly increased upwards. This is, at least partly, explained by the differences in reactivities of different monoterpenes. Camphene has lowest reactivity against $\mathrm{OH}$ and $\mathrm{O}_{3}$ of the monoterpenes analyzed (Atkinson, 1994). The average total monoterpene concentration in the surface layer was $63 \mathrm{ppt}_{v}$. Hakola et al. (2003) measured the average total surface layer concentrations of monoterpenes to be about $80 \mathrm{ppt}_{v}$ in March 2001 at SMEAR II. The average tempera- ture at this time was $-5^{\circ} \mathrm{C}$. This value as well as the monoterpene distribution is quite similar compared to our results. Also Rinne et al. (2000a) measured surface layer monoterpene distribution at SMEAR II in August 1998. They found almost similar distribution with somewhat higher proportion of $\alpha$-pinene and lower proportion of $\Delta^{3}$-carene. The total concentration in their measurement was about $500 \mathrm{ppt}_{v}$.

Higher in the boundary layer the average total monoterpene concentrations were $34 \mathrm{ppt}_{v}$ and $32 \mathrm{ppt}_{v}$ during QUEST II 2003 and LABACET 2006, respectively. Spirig et al. (2004) measured average monoterpene concentration to be $37 \mathrm{ppt}_{v}$ within mixed layer in August 2001 above Hyytiälä. This concentration is close to those values measured in the present study. Also the monoterpene distribution was quite close to our results except for the significant limonene concentrations measured by Spirig et al. (2004). Hakola et al. (2003) found out that limonene concentrations in the surface layer have stronger seasonal variation than other monoterpenes, with higher concentrations during summer and fall.

In Fig. 6 examples of vertical gradients of monoterpene concentrations are shown. The gradients are seldom well behaving although clear decreasing trend upwards can be seen. Figure $6 \mathrm{~b}$ shows how monoterpene concentrations suddenly dropped at nearly constant altitude. Some of these variations in the gradients may be explained by changes of vegetation inside measurement footprint during movement of the measurement platform. A large part of the variation is explained by analytical uncertainties of $17 \%$ up to $61 \%$ for different monoterpenes. The magnitudes of analytical uncertainties are calculated as mean relative standard deviation of parallel samples taken regularly at the SMEAR II station. Due to short sampling times in the present study, real uncertainties are likely to be even higher.

In addition to biogenic compounds, the concentration data of four VOCs of mainly anthropogenic origin are given in Table 4. The highest concentrations are those of benzene, being 179 ppt and 148 ppt during QUEST II 2003 and LABACET 2006, respectively. Figure 7 shows selected vertical gradients of benzene. For comparison, Hakola et al. (2006a) observed average benzene concentrations in the surface layer to be $211 \mathrm{ppt}_{v}$ and $28 \mathrm{ppt}_{v}$ in the winter and summer, respectively. Those surface air measurements were done at a rural site in the Northern Finland. Xylene concentrations varied a lot, average concentration being close to that of benzene. Emissions of these anthropogenic compounds can be assumed to be roughly constant throughout the year, but slower chemical degradation in the winter causes about ten-fold concentrations.

\subsection{Estimates of surface emissions}

The total landscape scale emission of monoterpenes varied between $5 \pm 4$ and $39 \pm 11 \mu \mathrm{g} \mathrm{m}^{-2} \mathrm{~h}^{-1}$ during QUEST II 2003 and between $0 \pm 10$ and $79 \pm 17 \mu \mathrm{g} \mathrm{m}^{-2} \mathrm{~h}^{-1}$ during 

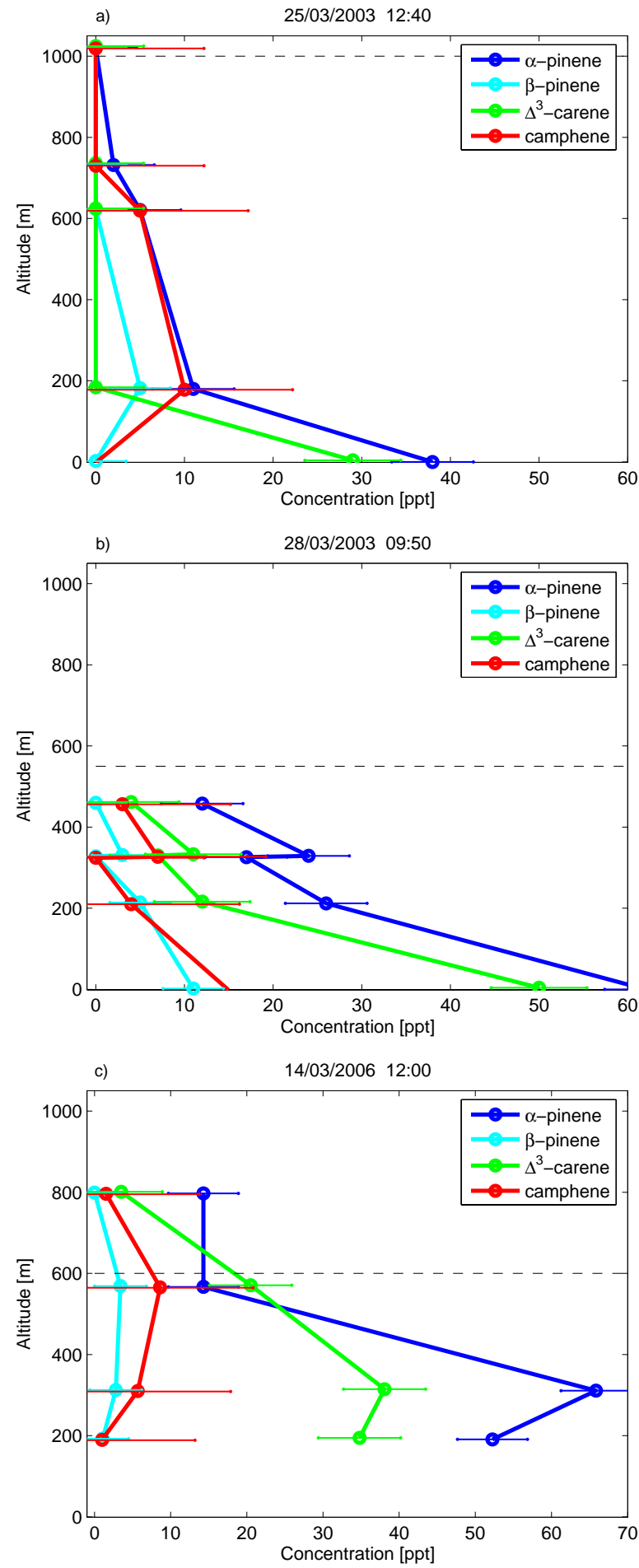

Fig. 6. Examples of vertical gradients of different monoterpene species. Dashed line indicates the height of boundary layer. Panels (a) and (b) originates from QUEST II 2003 aircraft flights and panel (c) from LABACET 2006 balloon flight.

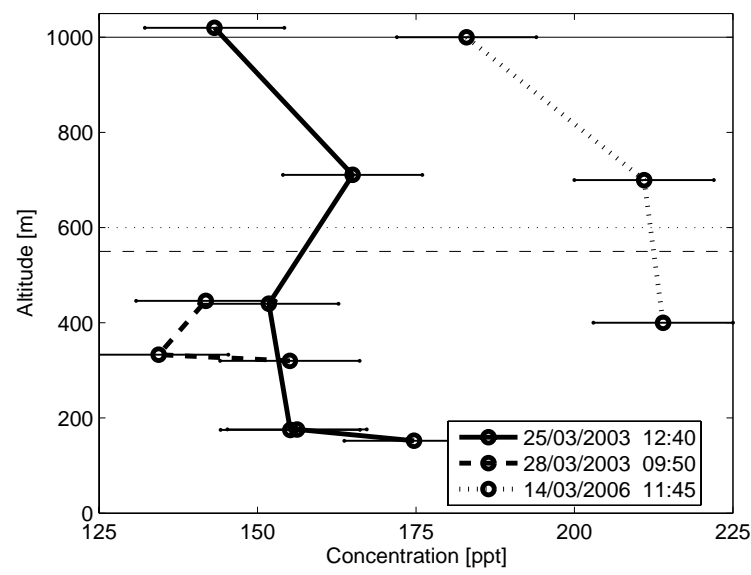

Fig. 7. Concentrations of benzene in the boundary layer on three days and corresponding boundary layer heights.

LABACET 2006. The dominant compound in the emissions was $\alpha$-pinene (see Fig. 8 and Table 5). Emission did not show clear dependence on the surface temperature (see Fig. 9) which can be due to very low temperatures and resulting low concentrations as compared to analytical uncertainties. The uncertainty estimates were obtained by standard error propagation. Uncertainties used in this analysis were: Boundary layer height $10 \%$, concentrations $17 \%-61 \%$ depending on the compound, $\mathrm{O}_{3}$ concentration $5 \%$, OH concentration $300 \%$, reaction rate constants $10 \%$.

We did not have observations on the growth rate of the boundary layer but from the boundary layer heights it was assumed to be less than $0.01 \mathrm{~m} \mathrm{~s}^{-1}$. Using the average boundary layer concentration of monoterpenes during LABACET $2006\left(0.17 \mu \mathrm{g} \mathrm{m}^{-3}\right)$ entrainment flux of less than $6 \mu \mathrm{g} \mathrm{m}^{-2} \mathrm{~h}^{-1}$ is obtained. Compared to average surface flux of monoterpenes $\left(38.4 \mu \mathrm{g} \mathrm{m}^{-2} \mathrm{~h}^{-1}\right)$ this means underestimation of about $16 \%$.

We calculated the landscape scale monoterpene emission potential using temperature dependent emission algorithm (Guenther et al., 1993) with commonly used temperature dependency factor $\beta=0.09^{\circ} \mathrm{C}^{-1}$. The standard emission potential obtained was $145 \mu \mathrm{g} \mathrm{m}^{-2} \mathrm{~h}^{-1}$. For comparison, we calculated the average landscape scale emissions using the same algorithm (Guenther et al., 1993), the land use data presented in Table 2, and emission potentials and foliar biomass densities for different forest types used by Lindfors and Laurila (2000). The resulting landscape scale emission potential of monoterpenes was $575 \mu \mathrm{g} \mathrm{m}^{-2} \mathrm{~h}^{-1}$, which leads to somewhat higher emissions than those derived in this paper. These curves are shown in the Fig. 9. Spirig et al. (2004) reported landscape scale emissions to be lower than ecosystem scale emissions measured before at the same place, which supports our results. 


\subsection{Estimates of production rate of condensable vapors}

We estimated the production rate of condensable vapors from the total oxidation rate of VOCs (Eq. 2). We assumed average formation yield of $8 \%$ from monoterpenes (e.g. Yu et al., 1999; Hoppel et al., 2001) and 4\% from aromatic compounds (e.g. Odum et al., 1996). The average total production rate of condensable vapors was $0.6 \times 10^{4}$ molecules $\mathrm{cm}^{-3} \mathrm{~s}^{-1}$ which is about half of the values reported by Spanke et al. (2001) and Spirig et al. (2004) at the same site. However, they both conducted measurements in August when temperature and hence emissions of biogenic compounds are substantially higher. In addition, oxidant levels are significantly higher at that time of the year. To study the annual cycle of production of condensable vapors from monoterpenes ( $\alpha$-pinene, $\beta$-pinene, $\Delta^{3}$-carene, camphene, sabinene and limonene) we used the concentration data measured by Hakola el al. (2003). From these data we calculated the monthly production rate in the similar manner for surface layer at about midday. In March the surface layer production turns out to be about threefold compared to our results representing the whole boundary layer. Further we can see the strong annual cycle peaking in the June-July, when temperature induced emissions of monoterpenes are highest together with fast oxidation due to strong solar radiation.

\section{Conclusions}

Boundary layer concentrations of volatile organic compounds were measured over boreal forests during early springs of 2003 and 2006. Due to short sampling times used in LABACET 2006 experiment, those results are somewhat more uncertain. Because of the ability to maintain stable flight altitude, aircraft seems to be better measurement platform than hot air balloon for this kind of work.

Despite of cold weather, the boundary layer concentrations of monoterpenes were at the same level than those measured in August at the same site during earlier studies. Isoprene, however, was almost absent. Although monoterpene concentrations were at the same level than in late summer, the production of condensable vapors was significantly reduced due to slower chemistry. Therefore, the aerosol formation events can not be explained solely by condensable vapors produced from those VOC compounds measured in this study. The concentrations of anthropogenic compounds were at the same level than those observed in the wintertime during earlier studies. Likewise for the biogenic compounds, the high concentrations are explained by the slow $\mathrm{OH}$ chemistry due to early time of year.

Landscape scale surface emissions were estimated using a simple mixed box method. The vertical profiles were not always well-behaving and therefore we did not use gradient methods. In the summer, the boundary layer might be somewhat better mixed and thus allows the usage of these

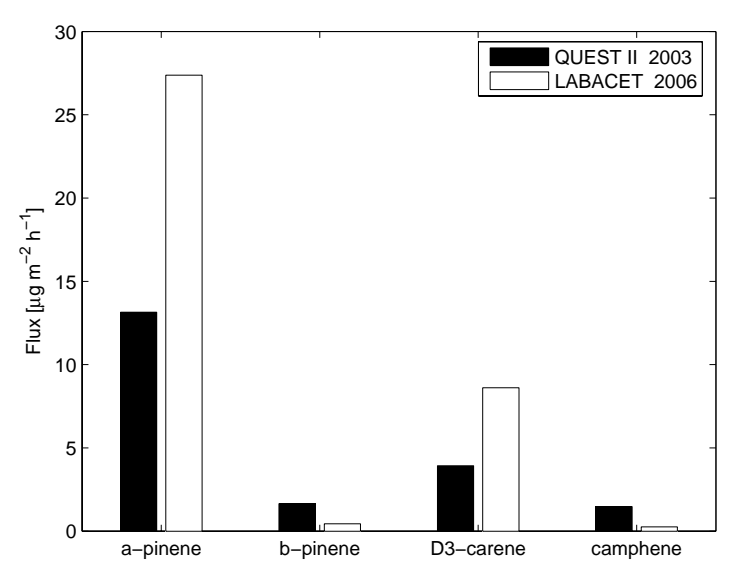

Fig. 8. Average fluxes of different monoterpene species during the two experiments.

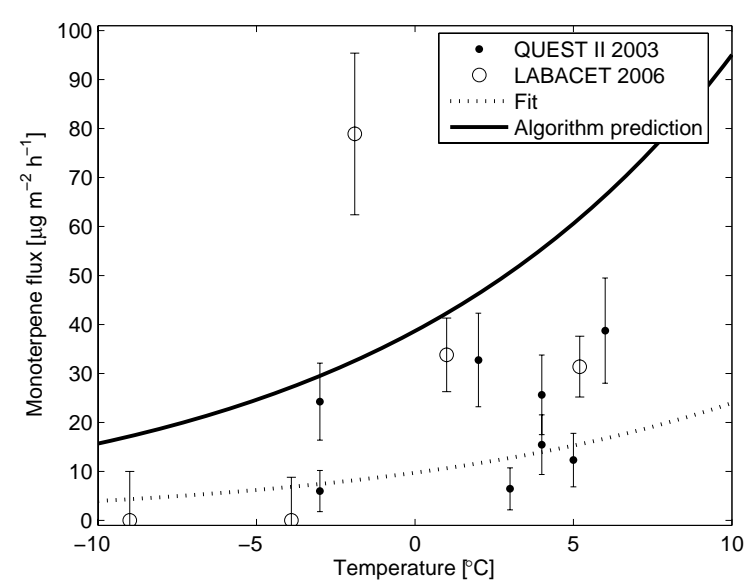

Fig. 9. Sum flux of monoterpenes versus surface temperature and fit to that dataset using temperature dependency coefficient $\beta=0.09^{\circ} \mathrm{C}^{-1}$. Solid black line shows algorithm prediction.

methods. Emissions of monoterpenes were lower than predicted by the ecosystem scale measurement data. Fitting of the measurement data to the Guenther emission algorithm yield to the landscape scale emission potential of only $145 \mu \mathrm{g} \mathrm{m}^{-2} \mathrm{~h}^{-1}$, which is considerably lower than one derived from previous emission measurements. In addition to the systematic underestimation caused by the mixed box method, this may indicate lower emission potential due to early season. The highest monoterpene emissions were those of $\alpha$-pinene and $\Delta^{3}$-carene, which is in line with previous measurements conducted over boreal forests.

Acknowledgements. J. Paatero is acknowledged for the measurements during aircraft flights. M. Sipinen, R. Lampinen, L. Kulmala, T. Ruuskanen and T. Grönholm are acknowledged for hot air balloon flights. S. Haapanala is grateful to the Academy 
Table 4. Statistics of the average VOC concentrations in $\mathrm{ppt}_{v}$. Data of QUEST II 2003 represents measurements during 8 different flights and data of LABACET 2006 represents measurements during 5 different flights. For further details of the flights see Table 1.

\begin{tabular}{|c|c|c|c|c|c|c|c|c|c|c|c|c|c|c|}
\hline & DL & UC & $\begin{array}{l}\text { QUEST } \\
\text { mean }\end{array}$ & $\begin{array}{l}\text { II } 2003 \\
\text { stdev }\end{array}$ & $\begin{array}{l}\text { surface } \\
\min \end{array}$ & $\begin{array}{l}\text { layer } \\
\max \end{array}$ & $\begin{array}{l}\text { QUEST } \\
\text { mean }\end{array}$ & $\begin{array}{c}\text { T II } 200 \\
\text { stdev }\end{array}$ & $\begin{array}{l}\text { boundar } \\
\text { min }\end{array}$ & $\begin{array}{c}\text { ry layer } \\
\max \end{array}$ & $\begin{array}{l}\text { LABA } \\
\text { mean }\end{array}$ & $\begin{array}{l}\text { CET } 200 \\
\text { stdev }\end{array}$ & $\begin{array}{l}6 \text { bound } \\
\text { min }\end{array}$ & $\begin{array}{c}\text { ary layer } \\
\max \end{array}$ \\
\hline isoprene & 10 & $4 \%$ & - & - & - & - & b.d.l. & b.d.1. & b.d.l. & b.d.l. & 6 & 2 & b.d.l. & 10 \\
\hline$\alpha$-pinene & 14 & $23 \%$ & 37 & 21 & b.d.l. & 62 & 15 & 9 & b.d.l. & 37 & 20 & 10 & 14 & 37 \\
\hline$\beta$-pinene & 2 & $17 \%$ & 3 & 5 & b.d.l. & 12 & 4 & 2 & b.d.l. & 9 & 1 & 2 & b.d.1. & 4 \\
\hline$\Delta^{3}$-carene & 4 & $27 \%$ & 21 & 19 & b.d.l. & 50 & 8 & 4 & b.d.l. & 18 & 10 & 9 & 4 & 25 \\
\hline camphene & 4 & $61 \%$ & 2 & 5 & b.d.l. & 15 & 7 & 4 & b.d.l. & 21 & 1 & 2 & b.d.l. & 5 \\
\hline Smonot. & & & 63 & & & & 34 & & & & 32 & & & \\
\hline benzene & 4 & $16 \%$ & - & - & - & - & 179 & 39 & 101 & 257 & 148 & 46 & 81 & 199 \\
\hline toluene & 46 & $34 \%$ & - & - & - & - & 108 & 72 & 38 & 285 & 61 & 27 & 46 & 108 \\
\hline $\mathrm{p} / \mathrm{m}$ xylene & 68 & $49 \%$ & - & - & - & - & 123 & 94 & 26 & 329 & 81 & 27 & 68 & 130 \\
\hline o xylene & 85 & $30 \%$ & - & - & - & - & 48 & 36 & 11 & 123 & 102 & 36 & 85 & 166 \\
\hline
\end{tabular}

$\mathrm{DL}=$ typical detection limit, $\mathrm{UC}=$ analytical uncertainty in $\%,-=$ not measured, b.d.1. = below detection limit

Table 5. Statistics of the VOC emissions in $\mu \mathrm{g} \mathrm{m}^{-2} \mathrm{~h}^{-1}$. Data of QUEST II 2003 represents measurements during 8 different flights and data of LABACET 2006 represents measurements during 5 different flights. For further details of the flights see Table 1.

\begin{tabular}{lllllllll}
\hline & \multicolumn{3}{c}{ QUEST II 2003 } & \multicolumn{5}{c}{ LABACET 2006 } \\
& mean & stdev & $\min$ & $\max$ & mean & stdev & $\min$ & $\max$ \\
\hline isoprene & b.d.1. & b.d.1. & b.d.1. & b.d.1. & 1.7 & 0.6 & b.d.l. & 2.8 \\
$\alpha$-pinene & 13.1 & 8.2 & 3.3 & 24.7 & 27.4 & 16.2 & 16.1 & 55.5 \\
$\beta$-pinene & 1.7 & 1.4 & 0.3 & 4.3 & 0.4 & 1.0 & b.d.1. & 2.2 \\
$\Delta^{3}$-carene & 3.9 & 3.2 & b.d.1. & 8.6 & 8.6 & 8.0 & 2.4 & 22.2 \\
camphene & 1.5 & 1.7 & b.d.1. & 4.9 & 0.3 & 0.5 & b.d.1. & 1.1 \\
Imonot. & 20.2 & & & & 38.4 & & & \\
benzene & 1,1 & 0,6 & 0,3 & 2,0 & 0.4 & 0.2 & 0.2 & 0.6 \\
toluene & 1,0 & 0,4 & 0,3 & 1,7 & 0.9 & 0.5 & 0.6 & 1.7 \\
p/m xylene & 3,3 & 2,4 & 1,5 & 8,7 & 4.6 & 1.7 & 3.3 & 7.7 \\
o xylene & 0,9 & 0,6 & 0,1 & 2,3 & 4.2 & 1.6 & 3.0 & 7.0 \\
\hline
\end{tabular}

b.d.l. = below detection limit

of Finland for financial support (project 206162). This work was partly supported by the European Comission under contract EVK2-CT2001-00127 (QUEST).

Edited by: K. Hämeri

\section{References}

Atkinson R.: Gas-phase tropospheric chemistry of organic compounds, J. Phys. Chem. Ref. Data Monog., 2, 216 pp, 1994.

Boy, M., Kulmala, M., Ruuskanen, T.M., Pihlatie, M., Reissell, A., Aalto, P. P., Keronen, P., Dal Maso, M., Hellén, H., Hakola, H., Jansson, R., Hanke, M., and Arnold, F.: Sulphuric acid closure and contribution to nucleation mode particle growth, Atmos. Chem. Phys., 5, 863-878, 2005, http://www.atmos-chemphys.net/5/863/2005/.

Cess, R. D., Zhang, M. H., Minnis, P., Corsetti, L., Dutton, E., Forgan, B. W., Garber, D. P., Gates, W. L., Hack, J. J., Harrison, E. F., Jing, X., Kiehl, J. T., Long, C. N., Morcette, J.-J., and Pot- ter, G. L.: Absorption of solar radiation by clouds: Observations versus models, Science, 267, 496-503, 1995.

Dal Maso, M., Kulmala, M., Riipinen, I., Wagner, R., Hussein,T., Aalto, P. P., and Lehtinen, K. E. J.: Formation and growth of fresh atmospheric aerosols: eight years of aerosol size distribution data from SMEAR II, Hyytiälä, Finland, Boreal Environ. Res., 5, 323-336, 2005.

Davis, K. J., Lenschow, D. H., and Zimmerman, P. R.: Biogenic nonmethane hydrocarbon emissions estimated from tethered balloon observations, J. Geophys. Res., 99, 25 587-25 598, 1994.

Drebs, A., Nordlund, A., Karlsson, P., Helminen, J., and Rissanen, P.: Climatological statistics of Finland 1971-2000. Finnish Meteorological Institute, Helsinki, 99 pp, ISBN 951-697-568-2, 2002.

Guenther, A. B., Zimmerman, P. R., Harley, P. C., Monson, R. K., and Fall, R.: Isoprene and Monoterpene Emission Rate Variability: Model Evaluations and Sensitivity Analyses, J. Geophys. Res., 98, 12 609-12 617, 1993.

Guenther, A., Zimmerman, P., Klinger, L., Greenberg, J., Ennis, C., Davis, K., Pollock, W., Westberg, H., Allwine, G., and Geron, C.: Estimates of regional natural volatile organic compound fluxes 
from enclosure and ambient measurements, J. Geophys. Res., 101, 1345-1359, 1996.

Haapanala, S., Rinne, J., Pystynen, K.-H., Hellén, H., Hakola, H., and Riutta, T.: Measurements of hydrocarbon emissions from a boreal fen using the REA technique, Biogeosci., 3, 103-112, 2006.

Hakola, H., Rinne, J., and Laurila, T.: The hydrocarbon emission rates of tea-leafed willow (Salix phylicifolia), silver birch (Betula pendula) and european aspen (Populus tremula), Atmos. Environ., 32, 1825-1833, 1998.

Hakola, H., Laurila, T., Rinne, J., and Puhto, K.: The ambient concentrations of biogenic hydrocarbons at a northern European, boreal site, Atmos. Environ., 34, 4971-4982, 2000.

Hakola, H., Tarvainen, V., Laurila, T., Hiltunen, V., Hellén, H., and Keronen, P.: Seasonal variation of VOC concentrations above a boreal coniferous forest, Atmos. Environ., 37, 1623-1634, 2003.

Hakola, H., Hellén, H., and Laurila, T.: Ten years of light hydrocarbons $\left(\mathrm{C}_{2}-\mathrm{C}_{6}\right)$ concentration measurements in background air in Finland, Atmos. Environ., 40, 3621-3630, 2006a.

Hakola, H., Tarvainen, V., Bäck, J., Ranta, H., Bonn, B., Rinne, J., and Kulmala, M.: Seasonal variation of mono- and sesquiterpene emission rates of Scots pine, Biogeosci., 3, 93-101, $2006 \mathrm{~b}$.

Hari, P. and Kulmala, M.: Station for measuring ecosystematmosphere relations (SMEAR II), Boreal Environ. Res., 5, 315322, 2005 .

Hellén, H., Hakola, H., Pystynen, K.-H., Rinne, J., and Haapanala, S.: C2-C10 hydrocarbon emissions from a boreal wetland and forest floor, Biogeosci., 3, 167-174, 2006.

Hoppel, W., Fitzgerald, J., Frick, G., Caffrey, P., Pasternack, L., Hegg, D., Gao, S., Leaitch, R., Shantz, N., Cantrell, C., Albreccinski, T., Ambrusko, J., and Sullivan, W.: Particle formation and growth from ozonolysis of $\alpha$-pinene, J. Geophys. Res., 106, 27 603-27 618, 2001.

Janson, R.: Monoterpene concentrations in and above a forest of Scots pine. J. Atmos. Chem., 14, 385-394, 1992.

Janson, R.: Monoterpene emissions from Scots pine and Norwegian spruce. J. Geophys. Res., 98, 2839-2850, 1993.

Janson, R., Rosman, K., Karlsson, A., and Hansson, H.-C.: Biogenic emissions and gaseous precursors to forest aerosols, Tellus B, 53, 423-440, 2001.

Kulmala, M., Suni, T., Lehtinen K. E. J., Dal Maso, M., Boy, M., Reissell, A., Rannik, Ü., Aalto, P., Keronen, P., Hakola, H., Bäck, J., Hoffmann, T., Vesala, T., and Hari, P.: A new feedback mechanism linking forests, aerosols, and climate, Atmos. Chem. Phys., 4, 557-562, 2004a.

Kulmala, M., Vehkamäki, H., Petäjä, T., Dal Maso, M., Lauri, A., Kerminen, V.-M., Birmili, W., and McMurry, P. H., Formation and growth rates of ultrafine atmospheric particles: a review of observations, J. Aerosol Sci., 35, 143-176, 2004 b.

Kurten, T., Kulmala, M., Dal Maso, M., Suni, T., Reissell, A., Vehkamäki, H., Hari, P., Laaksonen, A., Viisanen, Y., and Vesala, T.: Estimation of different forest-related contributions to the radiative balance using observations in Southern Finland, Boreal Environ. Res., 8, 275-285, 2003.

Lindfors, V. and Laurila, T.: Biogenic volatile organic compound (VOC) emissions from forests in Finland, Boreal Environ. Res., 5, 95-113, 2000.

Mäkelä, J. M., Aalto, P., Jokinen, V., Pohja, T., Nissinen, A., Palmroth, S., Markkanen, T., Seitsonen, K., Lihavainen, H., and Kul- mala, M.: Observations of ultrafine aerosol particle formation and growth in boreal forest, Geophys. Res. Lett., 24, 1219-1222, 1997.

O’Dowd, C. D., Aalto, P, Hämeri, K., Kulmala, M., and Hoffmann, T.: Atmospheric particles from organic vapours, Nature, 416, 497-498, 2002.

O’Dowd, C., Yoon, Y., Junkerman, W., Aalto, P., Kulmala, M., Lihavainen, H., and Viisanen Y.: Airborne measurements of nucleation mode particles I: coastal nucleation and growth rates, Atmos. Chem. Phys., 7, 1491-1501, 2007, http://www.atmoschem-phys.net/7/1491/2007/.

Odum, J., Hoffmann, T., Bowman, F., Collins, D., Flagan, R., and Seinfeld, J.: Gas/particle partitioning and secondary organic aerosol yields, Environ. Sci. Technol., 30, 2580-2585, 1996.

Ramanathan, V., Crutzen, P. J., Kiehl, J. T., and Rosenfeld, D.: Aerosol, climate and the hydrological cycle, Science, 294, 2119 2124, 2001.

Rinne, J., Hakola, H., and Laurila, T.: Vertical fluxes of monoterpenes above a Scots pine stand in the boreal vegetation zone, Phys. Chem. Earth (B), 24, 711-715, 1999.

Rinne, J., Hakola, H., Laurila, T., and Rannik, Ü.: Canopy scale monoterpene emissions of Pinus sylvestris dominated forests, Atmos. Environ., 34, 1099-1107, 2000a.

Rinne, J., Tuovinen, J.-P., Laurila, T., Hakola, H., Aurela, M., and Hypén, H.: Measurements of hydrocarbon fluxes by a gradient method above a northern boreal forest, Agric. Forest. Meteorol., 102, 25-37, 2000b.

Rinne, J., Ruuskanen, T. M., Reissell, A., Taipale, R., Hakola, H., and Kulmala, M.: On-line PTR-MS measurements of atmospheric concentrations of volatile organic compounds in a European boreal forest ecosystem, Boreal. Environ. Res., 10, 425436, 2005.

Seinfeld, J. H. and Pandis, S. N.: Atmospheric Chemistry and Physics: From Air Pollution to Climate Change, Wiley, New York, 1998.

Spanke, J., Rannik, Ü., Forkel, R., Nigge, W., and Hoffmann, T.: Emission fluxes and atmospheric degradation of monoterpenes above a boreal forest: field measurements and modelling, Tellus B, 53, 406-422, 2001.

Spirig, C., Guenther, A., Greenberg, J. P., Calanca, P., and Tarvainen, V.: Tethered balloon measurements of biogenic volatile organic compounds at a Boreal forest site, Atmos. Chem. Phys., 4, 215-229, 2004, http://www.atmos-chemphys.net/4/215/2004/.

Tarvainen, V., Hakola, H., Hellén, H., Bäck, J., Hari, H., and Kulmala, M.: Temperature and light dependence of the VOC emissions of Scots pine, Atmos. Chem. Phys., 5, 989-998, 2005, http://www.atmos-chem-phys.net/5/989/2005/.

Tunved, P., Hansson, H.-C., Kerminen, V.-M., Ström, J., Dal Maso, M., Lihavainen, H., Viisanen, Y., Aalto, P. P., Komppula, M., and Kulmala, M.: High Natural Aerosol Loading over Boreal Forests, Science, 312, 261-263, 2006.

Twomey, S.: Aerosols, clouds and radiation, Atmos. Environ., 25A, 2435-2442, 1991.

Yu, J., Cocker, D., Griffin, R., Flagan, R., and Seinfeld, J.: Gasphase oxidation of monoterpenes: Gaseous and particular products, J. Atmos. Chem., 34, 207-258, 1999. 